\title{
Congenital leptin deficiency: diagnosis and effects of leptin replacement therapy
}

\author{
Deficiência congênita de leptina: diagnóstico \\ e efeitos da terapia de reposição
} Gilberto Paz-Filho', Claudio Mastronardi', Tuncay Delibasi²,
Ma-Li Wong', Julio Licinio'

1 John Curtin School of Medical Research, The Australian National University, Canberra, Australia 2 Department of Endocrinology and Metabolism, Ankara Diskapi Training and Research Hospital Ankara, Turkey
Correspondence to:

Julio Licinio

Garran Rd, building 131

Acton, ACT 0200

Australia

Julio.licinio@anu.edu.au

Received on Jul/27/2010 Accepted on Sept/27/2010

\section{SUMMARY}

To describe our 10-year experience in treating leptin-deficient humans. Three adults and one boy presented with childhood-onset morbid obesity, hypogonadism and family history of obesity and early death. Serum leptin was inappropriately low. A recessive C105T leptin gene mutation was identified. Metabolic and endocrine assessments were conducted, before and while on and off leptin. The adults' body mass index decreased from $51.2 \pm 2.5$ to $29.5 \pm 2.8 \mathrm{~kg} / \mathrm{m}^{2}$. Serum lipids normalized, insulin resistance decreased, and one of the initially diabetic females became normoglycemic. Hypogonadotropic hypogonadism was reversed, and other changes were observed in the adrenal, sympathetic, somatotropic and thyroid functions. Leptin replacement therapy reverses endocrine and metabolic alterations associated with leptin deficiency. Some of these results may be extrapolated to other diseases. Arq Bras Endocrinol Metab. 2010;54(8):690-7

\section{SUMÁRIO}

Descrever nossa experiência de 10 anos tratando pacientes deficientes em leptina. Três adultos e um menino apresentaram obesidade mórbida com início na infância, hipogonadismo e história familiar de obesidade e morte precoce. A leptina sérica era inapropriadamente baixa. A mutação recessiva C105T no gene da leptina foi identificada. Avaliações metabólicas e endócrinas foram realizadas antes e durante o tratamento. 0 índice de massa corporal dos adultos baixou de $51,2 \pm 2,5$ para $29,5 \pm 2,8 \mathrm{~kg} / \mathrm{m}^{2}$. Houve normalização dos lipídios séricos, a resistência insulínica diminuiu e a paciente que era diabética se tornou normoglicêmica. 0 hipogonadismo hipogonadotrópico foi revertido e outras alterações foram observadas nas funções adrenal, simpática, somatotrópica e tireoidiana. A reposição de leptina reverte as alterações endócrinas e metabólicas associadas com a deficiência de leptina. Alguns desses resultados podem ser extrapolados para outras doenças. Arq Bras Endocrinol Metab. 2010;54(8):690-7

\section{INTRODUCTION}

$\mathrm{L}$ eptin is a hormone produced mainly by the white adipose tissue, with multiple actions in the endocrine and immune systems, including glucose homeostasis, reproduction, bone formation, tissue remodeling and inflammation (1). Leptin is a key regulator of energy homeostasis, by regulating energy intake and expenditure through its actions on the arcuate nucleus of the hypothalamus $(2,3)$. Leptin levels are positively correlated with fat mass, being increased in obesity $(4,5)$.
Among mice that are leptin-deficient $(a b / o b)$ or leptin-resistant $(d b / d b)$, blunted metabolic rate and hyperphagia are characteristic features and obesity is a hallmark feature (6-10). In particular, $o b / o b$ mice also have cellular immune deficiency, hypogonadotropic hypogonadism, hypercortisolism, decreased levels of growth hormone, type 2 diabetes and central hypothyroidism. This phenotype is prevented or even reversed with the administration of exogenous leptin.

In humans, leptin deficiency is observed in lipodystrophy syndromes, which present with low or 
absent leptin levels due to abnormal deposition and distribution of adipose tissue. In addition, congenital human leptin deficiency may also be caused by mutations in the leptin gene.

These forms of leptin deficiency due to mutations in the leptin gene are extremely rare, with 20 patients having been identified in the world to date. These are patients of Pakistani $(\mathrm{n}=12)(8,11,12)$, Turkish $(\mathrm{n}=5)(7,13,14)$, Egyptian $(\mathrm{n}=2)(15)$ and Austrian $(n=1)(16)$ background. The evaluation of those patients before and during leptin replacement therapy has unveiled the importance of leptin in the homeostasis of several systems, such as the brain, immunity and glucose metabolism.

In this manuscript, we have summarized the diagnostic approach and the phenotypic findings of five patients from a unique Turkish leptin-deficient family with a mutation in the leptin gene. Moreover, we describe the endocrine and metabolic effects of leptin replacement therapy in these patients.

\section{PATIENTS AND METHODS}

In 1998, investigators from the Gulhane Medical School in Ankara, Turkey and from the Cochin Institute of Molecular Genetics, University of Paris VII identified two adults (male A, 22-year-old; female B, 34-year-old) and one 6-year-old girl from Turkey, who presented with morbid obesity starting at early childhood, hypogonadotropic hypogonadism (in the adults), and extremely and unappropriately low serum leptin levels $(0.9 \mathrm{ng} / \mathrm{mL}$ for the adult male, $1.6 \mathrm{ng} /$ $\mathrm{mL}$ for the adult female, and $1.1 \mathrm{ng} / \mathrm{mL}$ for the girl). Due to this unique phenotype, the diagnosis of leptin deficiency was suspected.

Subsequently, a Mendelian recessive leptin gene mutation was identified, consisting of a $\mathrm{C} \rightarrow \mathrm{T}$ substitution in codon 105 of the leptin gene, resulting in an $\operatorname{Arg} \rightarrow \operatorname{Trp}$ replacement in the mature protein. That substitution abolishes an MspI restriction site, allowing rapid PCR screening for the mutation (7). This is the same mutation that is observed in the $o b / o b$ mouse where it causes a premature stop codon.

For the identification of the mutation, the coding region of exon 3 is amplified by PCR. Primers derived from the human sequence (GenBank accession no. NM_000230.2) were used. The sense primer (5'-CAGTCAGTCTCCTCCAAACA-3') corresponded to nucleotides 202-221, and the antisense primer
(5'-CTTAACGTAGTCCTTGCAGG-3') was complementary to nucleotides 580-600.

Subsequently, a restriction enzyme assay is performed with DNA of the PCR-amplified coding region of exon 3, digested by MspI. Since the mutation causes the disappearance of one of the two MspI sites, patients that are homozygous for the mutation will show only two bands of 29 and $370 \mathrm{bp}$ whereas patients without the mutation will have three bands of 29,139 , and 231 bp in the agarose gel. With regard to heterozygous patients, they will display 4 bands of $29,139,231$ and 370 bp (Figure 1). That particular mutation leads to the synthesis of a truncated protein that is not secreted into the medium, as evaluated in early functional studies (7).

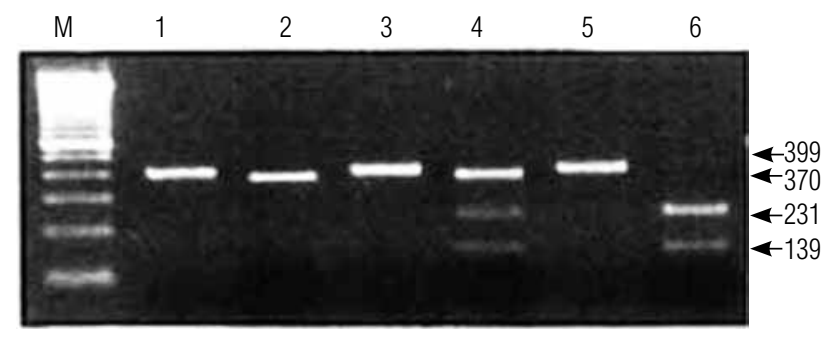

Patients 1 and 2 are homozygous, patients 3 and 4 are heterozygous, and patients 5 and 6 do not carry the C105T mutation of the leptin gene.

Samples 2, 4 and 6 were submitted to Msp/ digestion.

Figure 1. Agarose gel of homozygous, heterozygous and wild-type patients for the C105T mutation of the leptin gene. Adapted from (7) with permission.

In 1999, in collaboration with Ozata, we identified in this extended family a new adult homozygous female (patient C, 30-year-old) (13), who was severely obese and amenorrheic (6). Subsequently, a 5 -year-old boy (patient D) from the same pedigree was diagnosed with leptin deficiency. In this family, all but one wild-type and heterozygous individual had normal body weight, or were overweight. One heterozygous male individual (patients D's father) is obese (BMI of $32 \mathrm{~kg} / \mathrm{m}^{2}$ ), dyslipidemic (total cholesterol $=226 \mathrm{mg} / \mathrm{dL}$, triglycerides $=340 \mathrm{mg} / \mathrm{dL}, \mathrm{HDL}=30 \mathrm{mg} / \mathrm{dL}$ and $\mathrm{LDL}=128$ $\mathrm{mg} / \mathrm{dL}$ ) and has been recently diagnosed with type 2 diabetes in two oral glucose tolerance tests $(95 \mathrm{mg} / \mathrm{dL}$ at baseline and $206 \mathrm{mg} / \mathrm{dL} 2 \mathrm{~h}$ after $75 \mathrm{~g}$ of glucose).

Eight members of this family, whom we presume to have been leptin-deficient, had severe obesity and died during childhood due to infections. This number includes the 6 year-old girl, who died before the initiation of treatment. The pedigree chart is illustrated in figure 2 . 


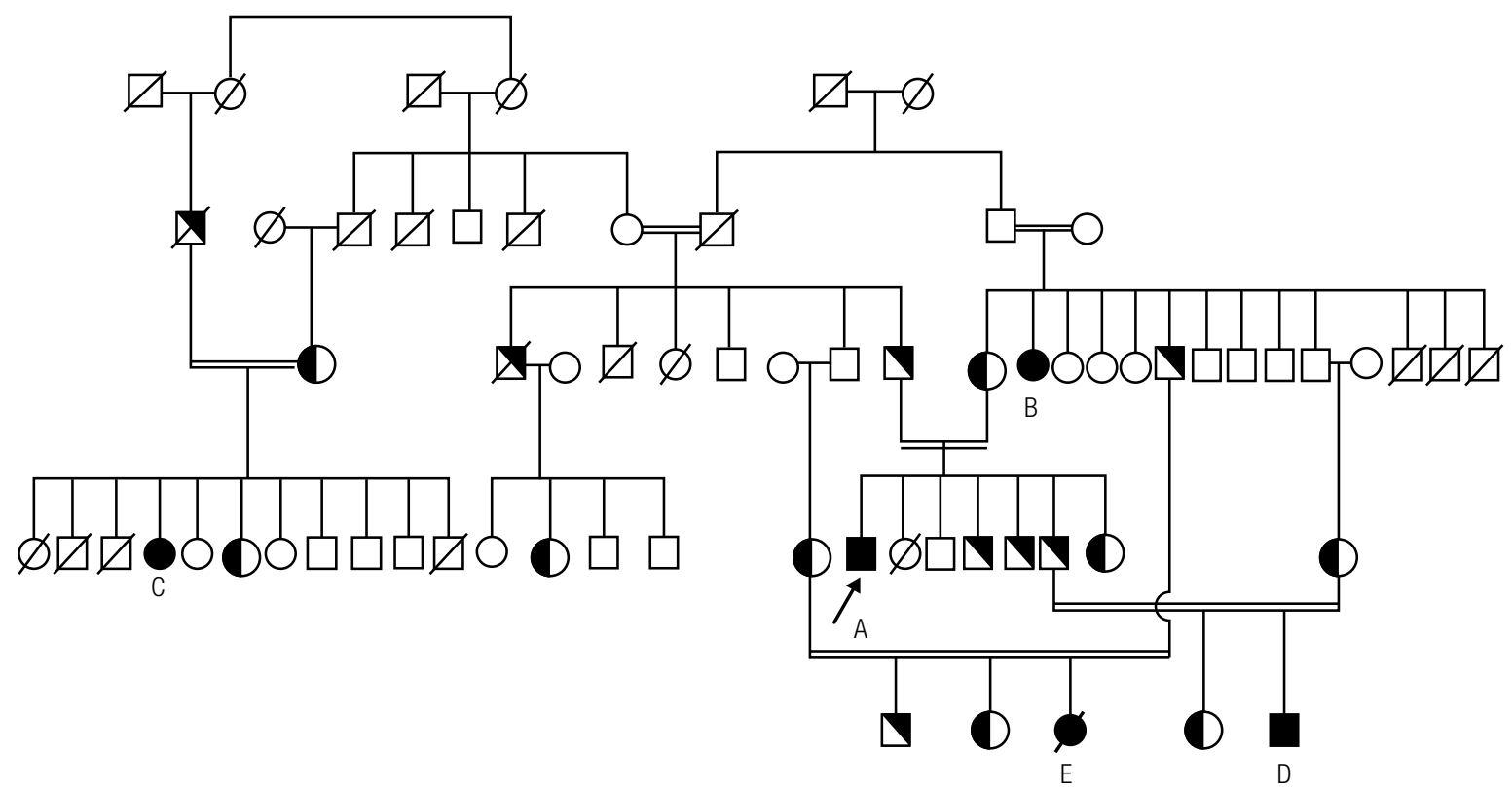

Figure 2. Pedigree chart of the Turkish cohort. Patient A: 34-year-old male; patient B: 44-year-old female; patient C: 49-year-old female; patient D: 10-yearold boy (actual ages); patient E: 9-year-old deceased girl.

\section{LEPTIN REPLACEMENT THERAPY}

At the diagnosis, clinical assessments of the endocrine, sympathetic, and immune functions were performed. Subsequently, over 10 years, we evaluated the effect of leptin replacement therapy with daily injection of recombinant methionyl human leptin (r-metHuLeptin, Amylin Pharmaceuticals, San Diego, USA). In addition, we assessed the effects of brief periods of leptin withdrawal and reinstitution.

Treatment with $\mathrm{r}$-metHuLeptin was initiated at ages 5 (boy - patient D), 27 (adult male - patient A), 30 and 40 (females B and C). Leptin replacement therapy is undertaken at low physiological doses, starting at $0.02-0.04 \mathrm{mg} / \mathrm{kg} /$ day given subcutaneously at $6 \mathrm{pm}$. A daily subcutaneous injection in the evening was chosen to mimic leptin's normal circadian rhythm, which peak occurs at night (17). For the adults, this dose increases serum leptin to levels that are normally observed in adult males with $20 \%$ body fat, or in adult females with $30 \%$ body fat. The child's initial dose was calculated to increase the peak serum leptin to $70 \mathrm{ng} /$ $\mathrm{mL}(18,19)$. Subsequently, doses were recalculated and scaled-down, avoiding excessively rapid weight loss.

The adults' initial mean dose was $4.1 \pm 1.2 \mathrm{mg} /$ day: $2.8 \mathrm{mg}$ for male patient A, $4.2 \mathrm{mg}$ for female patient $\mathrm{B}$, and $5.3 \mathrm{mg}$ for female patient $\mathrm{C}$. The current dose is $1.4 \pm 1.9 \mathrm{mg} /$ day: $0.3 \mathrm{mg}$ for $\mathrm{A}, 0.45 \mathrm{mg}$ for $\mathrm{B}$, and $3.6 \mathrm{mg}$ for C. The child's initial dose was $1.36 \mathrm{mg} /$ day, and the current dose is $0.95 \mathrm{mg}$. More significant decreases in leptin dose for patient $\mathrm{C}$ resulted in weight gain possibly because that patient presents higher leptin resistance, associated with common obesity.

\section{PHENOTYPE BEFORE AND DURING TREATMENT}

\section{Body composition, food intake and energy expenditure}

The most evident phenotypic finding in our patients was morbid obesity. The adults' initial mean body mass index (BMI) was $51.2 \pm 2.5 \mathrm{~kg} / \mathrm{m}^{2}\left(51.4,46.7\right.$, and $55.4 \mathrm{~kg} / \mathrm{m}^{2}$, for patients $\mathrm{A}, \mathrm{B}$, and $\mathrm{C}$ respectively). After 18 months of treatment, the patients reached a stable mean BMI of $26.9 \pm 2.1 \mathrm{~kg} / \mathrm{m}^{2}\left(24.8,26.1\right.$, and $31.3 \mathrm{~kg} / \mathrm{m}^{2}$ for $\mathrm{A}, \mathrm{B}$, and $C$ respectively) (Figures 3 and 4 ). Since early 2003 , the patients' weight has remained fairly stable, and the latest BMI (as of March 2010) was $29.5 \pm 2.8 \mathrm{~kg} / \mathrm{m}^{2}$. The boy also lost a significant amount of weight, going from a BMI of $39.6 \mathrm{~kg} / \mathrm{m}^{2}$ before treatment at age 5 , to $22.6 \mathrm{~kg} / \mathrm{m}^{2}$ at age 9 (Figure 5). Most of the decrease in BMI was attributed to fat mass loss, as measured by DXA (13). In 2001, the initial total body fat percentages were $43.7,45.7$, and $49.9 \%$ for patients $\mathrm{A}, \mathrm{B}$, and C, respectively. In 2007, those percentages were equal to 7.0, 36.4 , and $45.0 \%$, respectively for patients A, B, and C. 

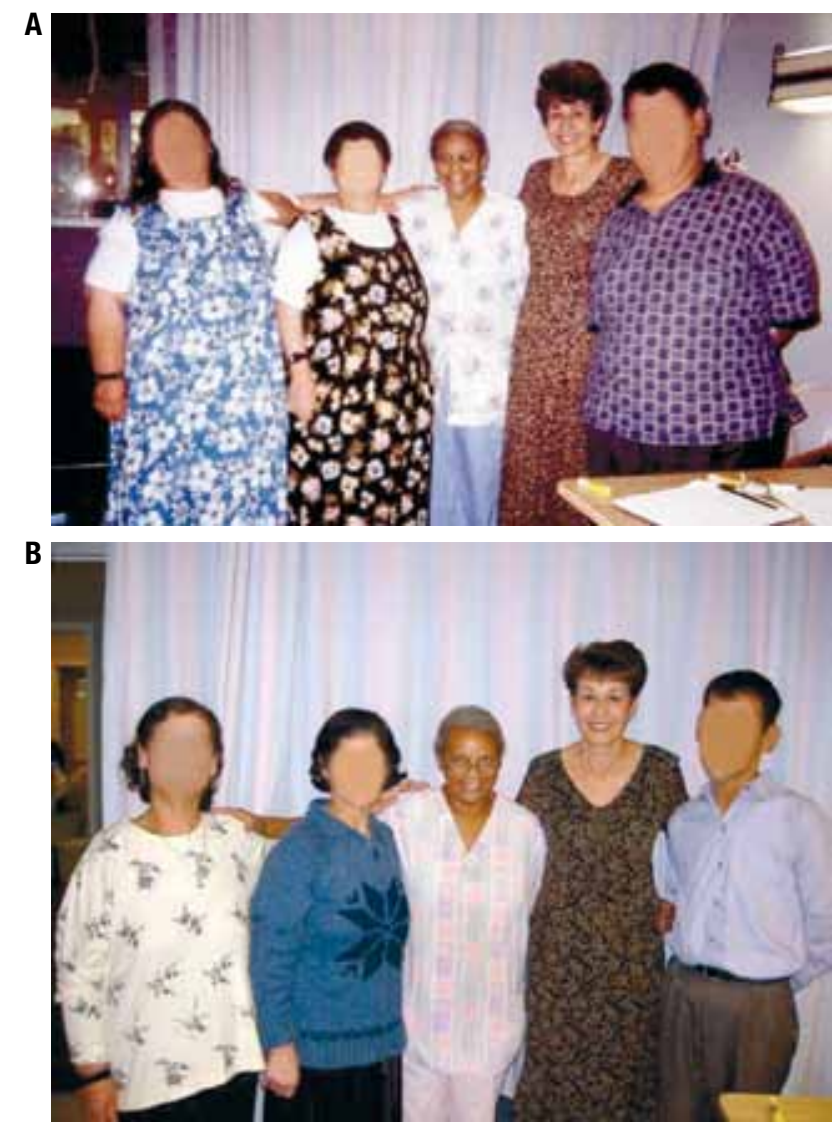

From left to the right: patients C, B and A (blurred faces), before (a) and 18 months after r-metHuLeptin treatment (b)

Figure 3. Adult patients before (A) and 18 months after treatment (B). Adapted from (13) with permission.

Before treatment, patient A had low bone mineral density (BMD) at the lumbar spine (BMD of L2-L4, $0.924 \mathrm{~g} / \mathrm{cm}^{2}$; T-score -1.96; Z-score -2.36), and the females had normal BMDs at all sites. After 6 years, the male's BMD at the lumbar spine increased by $11 \%$ (BMD of L2-L4, $1.042 \mathrm{~g} / \mathrm{cm}^{2}$; T-score -1.5; Z-score -1.1). The females' BMDs remained within normal range, without significant changes.

Weight loss was achieved without any instruction on dietary changes or on increase in physical activity. In the adults, leptin replacement decreased energy intake from $2,384 \pm 946 \mathrm{kcal} /$ day to $1,179 \pm 790 \mathrm{kcal} /$ day (Figure 4). In addition, leptin replacement changed the macronutrient content of the patients' diet, with an increase in carbohydrate and a decrease in fat consumption (20). In the child, after two years, caloric intake decreased from $2,709 \pm 370$ to $2,194 \pm 292 \mathrm{kcal} /$ day, which is $106 \%$ of the recommended caloric intake for a boy this age, height and weight (14). Activity levels were measured in the adults by actigraphy, which showed progressive and linear increases (13).
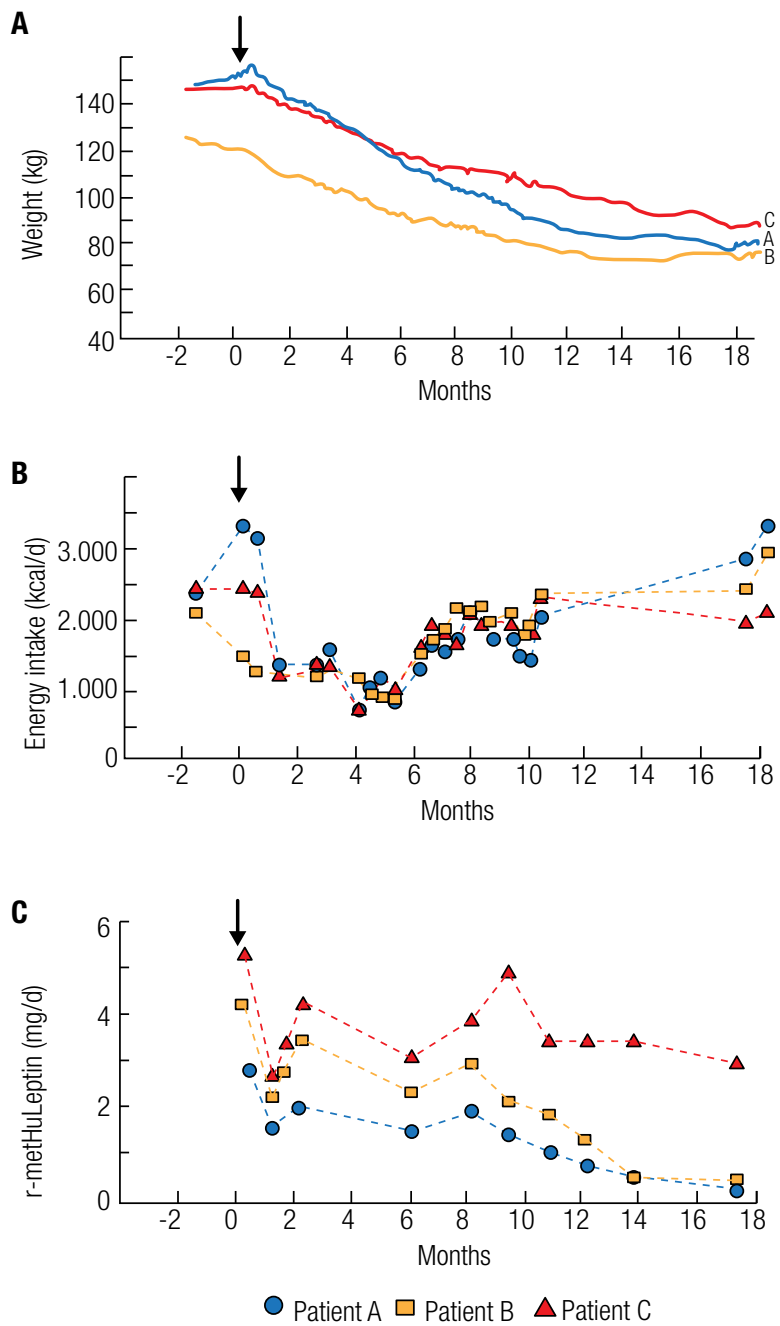

Figure 4. Weights $(A)$, energy intake $(B)$, and r-metHuLeptin dose $(C)$ over the first 18 months of treatment. Adapted from (13) with permission.

Before treatment, 24-h energy expenditure and 24-h fat oxidation in the adults were comparable to those of age-, sex- and weight-matched controls. During treatment, the weight loss-associated decrease in energy expenditure was less pronounced in our patients than in controls under a weight loss program. In addition, fat oxidation was also higher in our patients. Therefore, leptin replacement prevented the reduction in metabolic rate that is associated with weight loss (21).

\section{Lipid and glucose metabolism}

Before treatment, all patients had low HDL-cholesterol and normal or high triglycerides and insulin (Table 1). In addition, the older female was diagnosed with type 2 diabetes $(6,13)$. Leptin replacement normalized serum lipid, glucose and insulin levels, leading to the resolution of type 2 diabetes in patient $\mathrm{C}$ (13). These changes are sustained until the present time. 


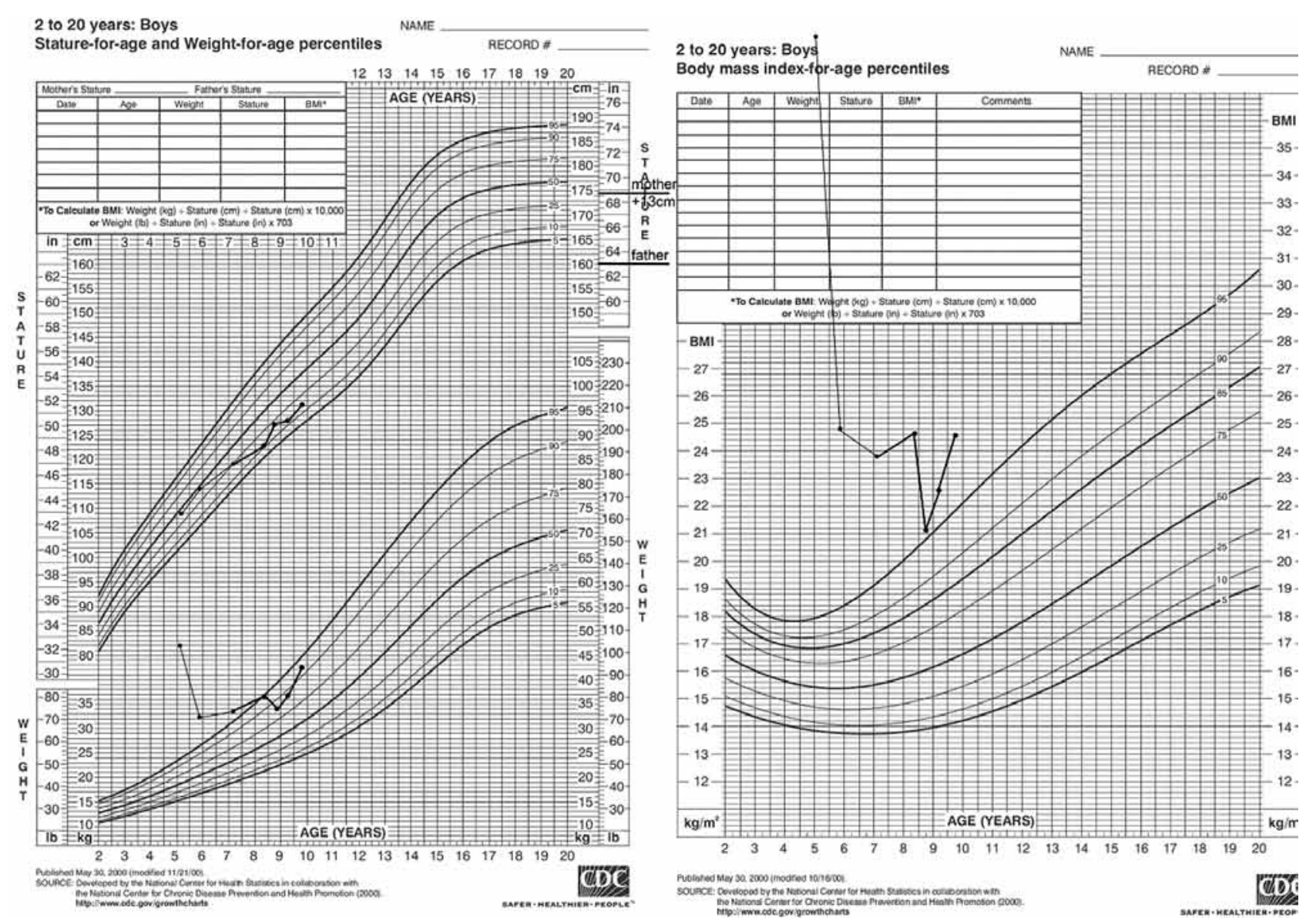

Figure 5. Patient's $D$ growth and body mass index charts. The patient experienced substantial weight gain in the last evaluation due to a brief period of shortage of supplies.

Table 1. Serum lipids, glucose and insulin before and after treatment

\begin{tabular}{|c|c|c|c|c|c|c|c|c|c|c|c|c|}
\hline & \multicolumn{2}{|c|}{$\begin{array}{c}\text { Total cholesterol } \\
\text { (mg/dL) }\end{array}$} & \multicolumn{2}{|c|}{$\begin{array}{l}\text { HDL-c } \\
\text { (mg/dL) }\end{array}$} & \multicolumn{2}{|c|}{$\begin{array}{l}\text { LDL-c } \\
\text { (mg/dL) }\end{array}$} & \multicolumn{2}{|c|}{$\begin{array}{l}\text { Triglycerides } \\
\text { (mg/dL) }\end{array}$} & \multicolumn{2}{|c|}{$\begin{array}{l}\text { Insulin } \\
\text { (uU/mL) }\end{array}$} & \multicolumn{2}{|c|}{$\begin{array}{l}\text { Glucose } \\
\mathrm{ng} / \mathrm{dL}\end{array}$} \\
\hline & Before & After\# & Before & After" & Before & After* & Before & After\# & Before & After\# & Before & After" \\
\hline A & 137 & 96 & 29.9 & 53.3 & 82 & 29 & 125 & 69 & 4.8 & 1.8 & 91 & 78 \\
\hline B & 115 & 110 & 36.8 & 51.2 & 62 & 49 & 79 & 47 & 3.8 & 1.8 & 88 & 84 \\
\hline C & 181 & 125 & 28.6 & 38.4 & 103 & 64 & 247 & 115 & 7.5 & 3.1 & 131 & 86 \\
\hline$D^{*}$ & 166 & 155 & 36 & 65 & 87 & 66 & 216 & 120 & 21 & 7 & 79 & 87 \\
\hline
\end{tabular}

* After 2 years; ${ }^{*}$ After 18 months.

By measuring glucose, insulin and C-peptide and mathematically modeling glucose homeostasis, during a 24-h period of intensive blood sampling (every 7 minutes; 207 samples in total $/ 24 \mathrm{~h}$ ), with standardized meals used as tolerance tests, we observed that leptin replacement increased insulin sensitivity by at least 5.7 fold, decreased pancreatic insulin secretion calculated by deconvolution of plasma C-peptide levels and also decreased hepatic extraction of insulin (22) estimated as the instantaneous differences between insulin secretion and post hepatic delivery rates.

During the $4^{\text {th }}, 5^{\text {th }}$, and $6^{\text {th }}$ year of treatment, the adults were submitted to brief periods of leptin withdrawal during 6 weeks, leading to substantial weight gain $(5.6 \pm 3.8 \mathrm{~kg}$ for patient $\mathrm{A}, 5.4 \pm 0.9 \mathrm{~kg}$ for patient $\mathrm{B}$, and $6.0 \pm 2.2 \mathrm{~kg}$ for patient $\mathrm{C}$ ). This weight gain determined an acute and transient increase in insulin sensitivity (measured by euglycemic hyperinsulinemic 
clamps) while off leptin, as the newly acquired adipose tissue absorbed glucose in excess (23).

\section{Gonadal and reproductive function}

Before treatment, the adults were hypogonadic. The adult male was prepuberal: no beard, bilateral gynecomastia, scanty pubic and axillary hair, small penis, small testis, and azoospermia. Patient $\mathrm{C}$ had spontaneous menarche at age 35 , and had scanty pubic and axillary hair, small uterus and ovaries, and no mammary tissue. The younger female had spontaneous menarche at age 29 , with normal pubic and axillary hair, small ovaries and borderline uterus, and diminished mammary tissue. Gonadotropin responses to GnRH stimulation were normal, which favors the diagnosis of hypogonadotropic hypogonadism (Table 2 ).

After treatment, menstrual periods became regular in both patients, with serial midluteal phase progesterone measurements $>10 \mathrm{ng} / \mathrm{mL}$, which are indicative of ovulation. The male adult's testosterone and free testosterone levels reached normal values for adults. All adults fully developed secondary sexual characteristics and developed normal sexual function (13).

\section{Adrenals and sympathetic tone}

Contrary to $o b / o b$ mice, leptin-deficient humans do not present with hypercortisolemia. Our patients had normal levels of free urinary cortisol. Serum cortisol levels were $11.5,22.3$, and $26.4 \mu \mathrm{g} / \mathrm{dL}$ for patients $\mathrm{A}, \mathrm{B}$, and $\mathrm{C}$ respectively. Those levels were suppressed to less than $5 \mu \mathrm{g} / \mathrm{dL}$ with $1 \mathrm{mg}$ of dexamethasone (6). Patient A was submitted to frequent blood sampling over 24 hours, which showed that leptin replacement increases the mean 24-hour levels of serum cortisol, from 4.04 $\pm 0.22 \mu \mathrm{g} / \mathrm{dL}$ to $5.97 \pm 0.30 \mu \mathrm{g} / \mathrm{dL}$. Leptin also altered the circadian rhythms of cortisol, by decreasing the number of pulses from 25 to 19 , increasing their amplitude, increasing the morning peak, and increasing regularity (13).

Low sympathetic tone was shown in the adults (patients $\mathrm{A}, \mathrm{B}$, and $\mathrm{C}$ ) and in the girl (patient E), evaluated by cold pressor response tests, by orthostatic hypotension tests, and by skin response tests. Results in the leptin-deficient patients (Table 3 ) were significantly different from 15 age- and sex-matched healthy controls, in which systolic cold pressor response was $10.6 \pm$ $0.37 \mathrm{mmHg}(\mathrm{z}=-4.74 ; \mathrm{P}<0.001)$ and diastolic cold pressor response was $12.0 \pm 0.38 \mathrm{mmHg}(\mathrm{z}=-4.754 ; \mathrm{P}$ $<0.001)$. Sympathetic function was normal in heterozygous and wild-type subjects (6).

In patient $\mathrm{A}$, there were no aldosterone and renin responses to the postural test: supine position: aldosterone $<10 \mathrm{pg} / \mathrm{mL}$; renin, $0.3 \mathrm{ng} / \mathrm{mL}$; upright position: aldosterone $<10 \mathrm{pg} / \mathrm{mL}$; renin, $0.3 \mathrm{ng} / \mathrm{mL}$. In patient $\mathrm{B}$, responses to the postural test were adequate: supine position: aldosterone $50.3 \mathrm{pg} / \mathrm{mL}$; renin 1.4 $\mathrm{ng} / \mathrm{mL}$; upright position: aldosterone $92.3 \mathrm{pg} / \mathrm{mL}$; renin $4.5 \mathrm{~g} / \mathrm{mL}$. In patient $\mathrm{C}$, the response was also adequate: supine position: aldosterone $25 \mathrm{pg} / \mathrm{mL}$; renin, $0.3 \mathrm{ng} / \mathrm{mL}$; upright position: aldosterone $127.5 \mathrm{pg} /$ $\mathrm{mL}$; renin, $4.8 \mathrm{ng} / \mathrm{mL}$.

Table 2. Sex hormones before treatment

\begin{tabular}{|c|c|c|c|c|c|c|}
\hline & \multicolumn{2}{|c|}{ FSH } & \multicolumn{2}{|c|}{ 내 } & \multirow{2}{*}{ Estrogen } & \multirow{2}{*}{ Total testosterone } \\
\hline & Before GnRH & Peak after GnRH & Before GnRH & Peak after GnRH & & \\
\hline A & 9 & 18.4 & 4.4 & 23.2 & 80.8 & 80.0 \\
\hline B & 6 & 9.6 & 5.3 & 18.4 & 53.0 & 53.0 \\
\hline C & 2.6 & 5.1 & 1.6 & 14.7 & 31.0 & 31.0 \\
\hline
\end{tabular}

Normal reference ranges for FSH (IU/L): 1.4-18.1; LH (IU/L): 1.5-9.3; estrogen (pg/mL): 21-76; total testosterone (ng/mL): 241-827 (male reference range).

Table 3. Cold pressor blood pressure and orthostatic hypotension tests is leptin-deficient humans before treatment.

\begin{tabular}{lccccc}
\hline & \multicolumn{2}{c}{ Cold pressor blood pressure response } & & \multicolumn{2}{c}{ Orthostatic hypotension test } \\
\cline { 2 - 3 } \cline { 5 - 6 } & Systolic & Diastolic & & $\begin{array}{c}\text { Systolic and diastolic pressure } \\
\text { before }\end{array}$ & $\begin{array}{c}\text { Systolic and diastolic pressure } \\
\text { after }\end{array}$ \\
\hline A & $7.2 \pm 0.16$ & $6.95 \pm 0.12$ & & $132.5 \pm 2.88 / 95.0 \pm 4.08$ & $91.2 \pm 2.5 / 61.2 \pm 2.5$ \\
$B$ & $7.22 \pm 0.17$ & $7.42 \pm 0.17$ & & $171.2 \pm 3.5 / 108.7 \pm 2.9$ & $143.2 \pm 5.3 / 80.0 \pm 4.1$ \\
C & $7.62 \pm 0.12$ & $7.2 \pm 0.13$ & & $123.7 \pm 2.9 / 72.5 \pm 2.8$ & $88.7 \pm 4.7 / 61.7 \pm 2.3$ \\
E & $7.57 \pm 0.17$ & $7.05 \pm 0.13$ & & $113.7 \pm 3.5 / 70.5 \pm 4.2$ & $86.7 \pm 2.2 / 62.7 \pm 2.2$ \\
\hline
\end{tabular}

Results in $\mathrm{mmHg}$. 


\section{Somatotropic axis}

The adult patients had no history of delayed or impaired growth, and their heights were within the family mean height. Growth hormone levels were $\leq 0.01 \mathrm{ng} /$ $\mathrm{mL}$, and responses to insulin-induced hypoglycemia and exercise tests were absent in the male (nadir glucose level, $37 \mathrm{mg} / \mathrm{dL}$; $\mathrm{GH}$ of $0.1 \mathrm{ng} / \mathrm{mL}$ in both tests) and in the younger adult female (nadir glucose level, 35 $\mathrm{mg} / \mathrm{dL} ; \mathrm{GH}, 0.1 \mathrm{ng} / \mathrm{mL}$ in the hypoglycemia test and $0.3 \mathrm{ng} / \mathrm{mL}$ in the exercise tests). Given the absence of clinical features of growth hormone deficiency, these results are probably attributed to obesity (6). Before treatment, the boy's height was at the $50^{\text {th }}$ percentile in the growth chart. Weight gain and growth deceleration was observed over 2 years (from the $50^{\text {th }}$ to the $10^{\text {th }}$ percentile), possibly due to inadequate dose adjustments. After leptin dose increases, the child is now between the $10^{\text {th }}$ and the $25^{\text {th }}$ percentile, within the targeted height (Figure 5).

In the adults, all of the IGF-related parameters were within normal range, except for postprandial IGFBP-1 (13). After 18 months of leptin replacement therapy (Table 4), we observed significant increases in pre and postprandial IGFBP-1 levels. We also observed significant increases in mean IGFBP-2, possibly attributed to the decrease in insulin levels (24).

Table 4. Mean insulin-like growth factors and insulin-like growth factor binding globulins, before and after treatment

\begin{tabular}{lcc}
\hline & Before & 18 months after \\
\hline IGF-I & $141 \pm 14$ & $154 \pm 16$ \\
IGF-II & $484 \pm 17$ & $487 \pm 17$ \\
IGFBP-1 (fasting) & $21.1 \pm 1.3$ & $140 \pm 42$ \\
IGFBP-1 (postprandial) & $3.7 \pm 0.5$ & $18.1 \pm 2.6$ \\
IGFBP-2 & $528 \pm 54$ & $936 \pm 53$ \\
IGFBP-3 & $1606 \pm 96$ & $1633 \pm 82$ \\
IGFBP-6 & $299 \pm 12$ & $282 \pm 12$ \\
\hline
\end{tabular}

Reference range values: IGF-I: $120-400 \mathrm{ng} / \mathrm{mL}$; IGF-II: $290-730 \mathrm{ng} / \mathrm{mL}$; IGFBP-1 (fasting): 13$120 \mathrm{ng} / \mathrm{mL}$; IGFBP-1 (postprandial): 10-30 ng/mL; IGFBP-2: 360-1020 ng/mL; IGFBP-3: 1500$3600 \mathrm{ng} / \mathrm{mL} ;$ IGFBP-6: 100-340 ng/mL.

\section{Thyroid function}

It is known that leptin has a circadian rhythm that is highly organized (18), and with a pattern similar to that of TSH: nadir in late morning and peak in the early morning (19). Although thyroid function tests were normal for all adults and for the boy (17), the leptin-deficient adult male (patient $\mathrm{A}$ ) presented dysregulated patterns of TSH pulsatile and circadian rhythms (25). Those data confirm that leptin has a role in regulating TSH secretion in humans (26), and its absence may lead to thyroid dysfunction. Leptin replacement did not increase free T4 or T3 (17), as previously observed in other studies (12).

\section{DISCUSSION}

Leptin replacement is currently the only successful hormonal treatment for a monogenic form of human obesity. In a cohort of Turkish leptin-deficient patients, our 10-year experience of leptin replacement therapy showed that treatment leads to substantial effects on body composition, food intake and energy expenditure, lipid and glucose metabolism, sympathetic tone, and gonadal, adrenal, somatotropic and thyroid functions. Additional results also suggest that leptin has important roles on non-endocrine parameters, such as inflammation and coagulation (27), immunity $(11,28)$, and brain structure and function (14,29-33).

Although leptin therapy has proven ineffective in treating patients with common and complex obesity, patients with severe forms of obesity and metabolic syndrome may present relatively low levels of leptin, corrected by adipose tissue mass (34). It is also known that specific polymorphisms in the leptin gene are associated with higher or lower leptin levels $(35,36)$. Therefore, obese patients with relatively low leptin levels, or with polymorphisms associated with lower leptin, might benefit from leptin therapy.

Although leptin deficiency is an extremely rare disease, our results provide new insight into the long-term effects of leptin in humans through a unique model of obesity presenting with leptin deficiency, without leptin resistance. By understanding the physiology of leptin, we will be able to design future studies that will evaluate the effects of leptin in other diseases, such as common obesity, lipodystrophy syndromes, diabetes, hypothalamic amenorrhea, anorexia nervosa, mood and cognitive disorders, immune deficiencies, and lipotoxicity.

Disclosure: no potential conflict of interest relevant to this article was reported.

Acknowledgements: We would like to thank Amgen Inc., and Amylin Pharmaceuticals for graciously providing recombinant methionyl human leptin at no cost. We also thank Dr. Amhet Yesilyurt for designing the pedigree chart. This work was funded by the National Institutes of Health Grants RR017365 and DK063240 (to M.-L.W.), RR016996 and DK058851 (to J.L.), and by The Australian National University institutional funds. 


\section{REFERENCES}

1. Kelesidis T, Kelesidis I, Chou S, Mantzoros CS. Narrative review: the role of leptin in human physiology: emerging clinical applications. Ann Intern Med. 2010;152:93-100.

2. Friedman JM. Leptin, leptin receptors, and the control of body weight. Nutr Rev. 1998;56:s38-46.

3. Velloso LA. The hypothalamic control of feeding and thermogenesis: implications on the development of obesity. Arq Bras Endocrinol Metabol. 2006;50:165-76.

4. Boucher J, Castan-Laurell I, Daviaud D, Guigne C, Buleon M, Carpene $C$, et al. Adipokine expression profile in adipocytes of different mouse models of obesity. Horm Metab Res. 2005;37:761-7.

5. Feitosa AC, Mancini MC, Cercato C, Villares SM, Halpern A. Metabolic profile according to leptin levels in obese patients. Arq Bras Endocrinol Metabol. 2007;51:59-64.

6. Ozata M, Ozdemir IC, Licinio J. Human leptin deficiency caused by a missense mutation: multiple endocrine defects, decreased sympathetic tone, and immune system dysfunction indicate new targets for leptin action, greater central than peripheral resistance to the effects of leptin, and spontaneous correction of leptinmediated defects. J Clin Endocrinol Metab. 1999;84:3686-95.

7. Strobel A, Issad T, Camoin L, Ozata M, Strosberg AD. A leptin missense mutation associated with hypogonadism and morbid obesity. Nature Genet. 1998;18:213-5.

8. Montague CT, Farooqi IS, Whitehead JP, Soos MA, Rau H, Wareham NJ, et al. Congenital leptin deficiency is associated with severe early-onset obesity in humans. Nature. 1997;387:903-8.

9. Farooqi IS, Jebb SA, Langmack $\mathrm{G}$, Lawrence $\mathrm{E}$, Cheetham $\mathrm{CH}$, Prentice AM, et al. Effects of recombinant leptin therapy in a child with congenital leptin deficiency. N Engl J Med. 1999;341:879-84.

10. Zhang $Y$, Proenca R, Maffei M, Barone M, Leopold L, Friedman JM. Positional cloning of the mouse obese gene and its human homologue. Nature. 1994;372:425-32.

11. Farooqi IS, Matarese G, Lord GM, Keogh JM, Lawrence E, Agwu $C$, et al. Beneficial effects of leptin on obesity, $T$ cell hyporesponsiveness, and neuroendocrine/metabolic dysfunction of human congenital leptin deficiency. J Clin Invest. 2002;110:1093-103.

12. Gibson WT, Farooqi IS, Moreau M, DePaoli AM, Lawrence E, O'Rahilly S, et al. Congenital leptin deficiency due to homozygosity for the Delta133G mutation: report of another case and evaluation of response to four years of leptin therapy. J Clin Endocrinol Metab. 2004;89:4821-6.

13. Licinio J, Caglayan S, Ozata M, Yildiz BO, de Miranda PB, O'Kirwan $F$, et al. Phenotypic effects of leptin replacement on morbid obesity, diabetes mellitus, hypogonadism, and behavior in leptindeficient adults. Proc Natl Acad Sci U S A. 2004;101:4531-6.

14. Paz-Filho GJ, Babikian T, Asarnow R, Delibasi T, Esposito K, Erol $\mathrm{HK}$, et al. Leptin replacement improves cognitive development. PLoS One. 2008;3:e3098.

15. Mazen I, El-Gammal M, Abdel-Hamid M, Amr K. A novel homozygous missense mutation of the leptin gene (N103K) in an obese Egyptian patient. Mol Genet Metab. 2009;97:305-8.

16. Fischer-Posovszky P, von Schnurbein J, Moepps B, Lahr G, Strauss G, Barth TF, et al. A new missense mutation in the leptin gene causes mild obesity and hypogonadism without affecting T cell responsiveness. J Clin Endocrinol Metab. 2010;95:2836-40.

17. Paz-Filho G, Delibasi T, Erol HK, Wong ML, Licinio J. Congenital leptin deficiency and thyroid function. Thyroid Res. 2009;2:11.

18. Licinio J, Mantzoros C, Negrao AB, Cizza G, Wong ML, Bongiorno $\mathrm{PB}$, et al. Human leptin levels are pulsatile and inversely related to pituitary- adrenal function. Nature Medicine. 1997;3:575-9.

19. Mantzoros CS, Ozata M, Negrao AB, Ziotopoulou M, Caglayan S, Suchard $\mathrm{M}$, et al. Synchronicity of frequently sampled TSH and leptin concentrations in healthy adults and leptin deficient subjects: evidence for possible partialTSH regulation by leptin in humans. J Clin Endocrinol Metab. 2001;86:3284-91.

20. Licinio J, Ribeiro L, Busnello JV, DelibasiT, Thakur S, Elashoff RM, et al. Effects of leptin replacement on macro- and micronutrient preferences. Int J Obes (Lond). 2007;31:1859-63.

21. Galgani JE, Greenway FL, Caglayan S, Wong ML, Licinio J, Ravussin E. Leptin replacement prevents weight loss-induced metabolic adaptation in congenital leptin-deficient patients. J Clin Endocrinol Metab. 2010;95:851-5.

22. Andreev VP, Paz-Filho G, Wong ML, Licinio J. Deconvolution of insulin secretion, insulin hepatic extraction post-hepatic delivery rates and sensitivity during 24-hour standardized meals: time course of glucose homeostasis in leptin replacement treatment. Horm Metab Res. 2009;41:142-51.

23. Paz-Filho G, Esposito K, Hurwitz B, Sharma A, Dong C, Andreev $V$, et al. Changes in insulin sensitivity during leptin replacement therapy in leptin-deficient patients. Am J Physiol Endocrinol Metab. 2008;295:E1401-8.

24. Wheatcroft SB, Kearney MT. IGF-dependent and IGF-independent actions of IGF-binding protein-1 and -2: implications for metabolic homeostasis. Trends Endocrinol Metab. 2009;20:153-62.

25. Mantzoros CS, Ozata M, Negrao AB, Suchard MA, Ziotopoulou M, Caglayan $\mathrm{S}$, et al. Synchronicity of frequently sampled thyrotropin (TSH) and leptin concentrations in healthy adults and leptin-deficient subjects: evidence for possible partial TSH regulation by leptin in humans. J Clin Endocrinol Metab. 2001;86:3284-91.

26. Moura EG, Moura CC. Regulation of thyrotropin synthesis and secretion. Arq Bras Endocrinol Metabol. 2004;48:40-52.

27. Paz-Filho GJ, Andrews D, Esposito K, Erol HK, Delibasi T, Wong $M L$, et al. Effects of leptin replacement on risk factors for cardiovascular disease in genetically leptin-deficient subjects. Horm Metab Res. 2009;41:164-7.

28. Paz-Filho GJ, Delibasi T, Erol HK, Wong ML, Licinio J. Cellular immunity before and after leptin replacement therapy. J Pediatr Endocrinol Metab. 2009;22:1069-74.

29. Baicy K, London ED, Monterosso J, Wong ML, Delibasi T, Sharma $A$, et al. Leptin replacement alters brain response to food cues in genetically leptin-deficient adults. Proc Natl Acad Sci U S A. 2007;104:18276-9.

30. Matochik JA, London ED, Yildiz BO, Ozata M, Caglayan S, DePaoli AM, et al. Effect of leptin replacement on brain structure in genetically leptin-deficient adults. J Clin Endocrinol Metab. 2005;90:2851-4.

31. Farooqi IS, Bullmore E, Keogh J, Gillard J, O'Rahilly S, Fletcher $P C$. Leptin regulates striatal regions and human eating behavior. Science. 2007;317:1355.

32. Lieb W, Beiser AS, Vasan RS, Tan ZS, Au R, Harris TB, et al. Association of plasma leptin levels with incident Alzheimer disease and MRI measures of brain aging. JAMA. 2009;302:2565-72.

33. Paz-Filho G, Wong ML, Licinio J. Leptin levels and Alzheimer disease. JAMA. 303:1478; author reply -9.

34. da Paz-Filho GJ, Volaco A, Suplicy HL, Radominski RB, Boguszewski CL. Decrease in leptin production by the adipose tissue in obesity associated with severe metabolic syndrome. Arq Bras Endocrinol Metabol. 2009;53:1088-95.

35. Hinuy HM, Hirata MH, Forti N, Diament J, Sampaio MF, Armaganijan $D$, et al. Leptin G-2548A promoter polymorphism is associated with increased plasma leptin and BMI in Brazilian women. Arq Bras Endocrinol Metabol. 2008;52:611-6.

36. Hinuy HM, Hirata MH, Sampaio MF, Armaganijan D, Arazi SS, Salazar LA, et al. Relationship between variants of the leptin gene and obesity and metabolic biomarkers in Brazilian individuals. Arq Bras Endocrinol Metabol. 54:282-8. 